EISSN: 2706 -7947 ISSN: 2077- 4613

DOI: $10.36632 /$ mejas/2021.11.4.76

Journal homepage: www.curresweb.com

Pages: 975-990

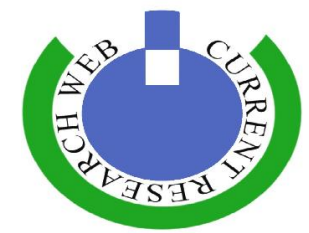

\title{
Differentiation of Essential Oil Components after Grx2 Gene Transfer of Lemon Basil Ocimum citriodorum
}

\author{
Sherif S. Saleh ${ }^{1,2}$ and Hoda A.S. El-Garhy ${ }^{3}$ \\ ${ }^{1}$ Tissue Culture and Nanotechnology Lab., Hort., Res., Institute, A. R. C., Egypt \\ ${ }^{2}$ Medicinal and Aromatic Department, Hort., Res., Institute, A. R. C., Egypt \\ ${ }^{3}$ Genetic and Genetic engineering Department, Agriculture of Faculty, Benha University, Egypt
}

Received: 14 Oct. $2021 \quad$ Accepted: 15 Nov. $2021 \quad$ Published: 30 Nov. 2021

\begin{abstract}
Development of transgenic Lemon basil (Ocimum citriodorum), plants harboring glutaredoxin- 2 gene $(G R X-2)$ was aimed. The first trial, including micropropagation of basil seeds, seeds disinfecting by sodium hypochloride at 5, 10 and $20 \%$ for 4,10 and 20 min or $\mathrm{HgCl}_{2}$ at $0.1,0.2$ and $0.3 \%$ for 5, 10 and 15 min. following by shootlet proliferation by seedlings subculture on MS media supplemented with BAP at 1.0, 2.0 and $3.0 \mathrm{mg} / \mathrm{l}$ and $\mathrm{Kin}$ at $0.1,0.2$ and $0.3 \mathrm{mg} / \mathrm{l}$ with their interactions. Finally, rooting production and proliferation by transfer initiated shootlets on MS media containing BAP at $0.25,0.5$ and $0.75 \mathrm{mg} / \mathrm{l}$ plus IBA at $0.25,0.5$ and $0.75 \mathrm{mg} / \mathrm{l}$. Essential oil was fractionated and determinated for un-transgenic and transgenic explants by GC-MS. The best results were toned in case of the successive disinfecting seeds by $\mathrm{Na}$ hypochloride at $10 \%$ for $10 \mathrm{~min}$ with decontamination percentage $81 \%$ and survival $66.66 \%$ followed by the seedlings of best growth on MS media containing $3 \mathrm{mg} / \mathrm{l}$ BAP (shoot No. 8.12, shoot length 9.12 and leaves No. 17.45). The roots formed at $0.75 \mathrm{mg} / 1$ IBA plus $0.25 \mathrm{mg} / \mathrm{l}$ BAP (rooting \% 100; root no. 12.12 and $1.34 \mathrm{~cm}$ root length). The second experiment was conducted to describe the possibility of producing transgenic basil plants harbouring the $G R X-2$ gene, conferring essential oil stability. To achieve this goal, micronodes of basil explants were transformed using Agrobacterium tumefaciens strain LBA4404 harbouring the binary plasmid pRI101 on DNA which contains $G R X-2$ gene, and the selectable marker gene neomycin phosphotransferase II (nptII) under the control of a CaMV35S promoter and nopaline synthase (nos) terminator. Molecular analysis using PCR analysis proved the presence and integration of the transgenes in the genome of the transgenic plants. The explants exposed to acetosyringone at $150 \mathrm{uM}$ for $60 \mathrm{~min}$ and immersion in Agrobacterium tumefaciens for $60 \mathrm{~min}$ and re-culture on MS medium gave the highest transformation efficiency and best growth. The GC analysis showed decrease in linalool components and the presence of limonene.
\end{abstract}

Keywords: Lemon basil, Glutaredoxin GRX2, Salinity, Transformation, Regeneration.

\section{Introduction}

Medicinal plants are one of the most important sources of drugs which are formulated by pharmaceutical company. Today the large numbers of drugs in use are derived from plants and are used as anticancer, antioxidant, analgesic and antidiabetic. The plants are rich in secondary metabolites and contain essential oils of therapeutic importance (Prakash and Gupta, 2005).

Lemon balm (Melissa officinalis), one of the Lamiaceae family plant (formerly Labiatae), is one of the important medicinal plant species. It has been traditionally used for different medicinal purposes as tonic, antispasmodic, carminative, diaphoretic, surgical dressing for wounds, sedative-hypnotic strengthening of the memory, and relief of stress induced headache, but in modern pharmacology its value is in the control of mild to moderate Alzheimer's, against migraine and rheumatism, antitumel and antioxidant activities (Moradkhani et al. 2010). In addition basil essential oils have been shown to possess antiviral and antimicrobial activity (Allahverdiyev et al. 1994; Dikbaş et al. 2010).

Corresponding Author: Sherif S. Saleh, Tissue Culture and Nanotechnology Lab., Hort., Res., Institute, A.R.C., Egypt. E-mail: sherif_saied_saleh@yahoo.com 
Also, ocimum species are herbaceous plants rich of essential oils with aromatic flavor and medicinal importance. Among them, lemon basil is widely used as stomatic, antihelminthic, antipyretic, diaphoretic, expectorant, carminative, pectoral and stimulant. It is a herb grown primarily in northeastern Africa and southern Asia and its strong fragrant lemon scent is used for cooking. The lemon basil has stems that can grow to $20-40 \mathrm{~cm}$ tall. At the late summer the plant has white flowers to early fall. Also, the leaves are like to basil leaves. The seeds were formation on the plant after flowering and dry on the plant (Patel et al., 2016).

The glutathione at high concentrations along with high GSH/GSSG redox potential has been suggested to confer better antioxidative protection and might be considered an acclimation against the stress factor (Tausz et al. 2004). Grxs gene have important biological functions in plants, such as oxidative stress responses, iron-sulfur (FeS) cluster assembly, and cell signaling, etc. (Rouhier et al. 2008). In plant cell, antioxidant enzymes such as polyphenyl oxidase (PPO), peroxidase (POD) and catalase (CAT) have been considered as defensive team, whose combined purpose is to protect cells from oxidative damage These findings suggest that the induction of reactive oxygen species (ROS) scavenging enzymes, such as PPO, POD and CAT, is the most common mechanism of salt tolerance for detoxifying ROS synthesized (Ros et. al. 1987; Gao 2008 and Koca et al. 2007).

Plant tissue culture refers to the in vitro culture of plants from plant parts (tissues, organs, embryos, single cells, protoplasts, etc.) on nutrient media under aseptic conditions (Altman, 2000). In vitro cultures are now being used as tools for the study of various problems in plant sciences. It is now possible to propagate all plants of economic importance in large numbers by tissue culture (Hameed et al., 2006). In vitro micropropagation is an effective way to obtain a high progeny uniformity of medicinal plants. Many in vitro studies have been conducted on Lamiaceae species, including the Ocimum genus, using different explants, like nodal segments (Begun et al., 2000) and leaf explants (Phippen and Simon, 2000). The widespread screening of plants for possible medicinal and antioxidant properties, the isolation and characterization of diverse phytochemicals and the development and utilization of antioxidants of natural origin (Gulcin et al., 2002). The present study was, therefore, carried out to describe impact of growth hormone on in vitro micropropagation of Ocimum citriodorum plant and the facility of receiving a foreign DNA in its plant cells.

\section{Material and methods}

\subsection{Collection of Ocimum citriodorum:}

Healthy and vigor seeds of Ocimum citriodorum were collected and cleaned from any dust, insect infections and washing by tap water to prepare of in vitro culture in Tissue Culture Res. Lab. Hort. Res., Institute, A.R.C. Egypt. The explants obtained from seeds were taken from these plants for all experiments.

\subsection{Explant preparation \\ 2.3. Basil lemon in vitro preparation \\ 2.3.1. Seed disinfection}

The seeds were collected from Agrogreen Company in the growth season 2020/2021 and were divided into groups each one contains more than 50 seeds. The seeds were washed in septol soap water for $30 \mathrm{~min}$ and rinsed with running tap water for one hour. Seeds were transferred under laminar flow cabinet and washed three times with sterile distilled water. Then seeds were immersed in $70 \%$ ethanol solution (v/v) for $30 \mathrm{sec}$. and washed in $10 \%$ Clorox (commercial bleach containing $2.25 \%$ sodium hypochlorite) plus tween-20 (2 drops / $100 \mathrm{ml})$ as emulsifier for 15 min with agitation under aseptic conditions and then rinsed in sterile distilled water for three times.

\subsubsection{Seed germination}

The sterilized seeds were germinated on free hormone MS media and the seedlings were transferred on proliferation free hormone MS medium.

\subsubsection{Culture conditions:}

Cultures were maintained in the culture room at $28 \pm 1{ }^{\circ} \mathrm{C}$ under $16 \mathrm{~h}$ photoperiod provided by cool white fluorescent light followed by $18 \mathrm{~h}$ dark period for 45 days. Three repetitions per treatment were used and the data were submitted to variance analysis. 


\subsubsection{Shoot proliferation:}

Explants from node and leaf derived callus explants of Ocimum citriodorum plant were inoculated on MS basal medium supplemented with individual concentrations and combinations of BA $(0.25,0.5$, 0.75 and $1.0 \mathrm{mg} / \mathrm{l}) \mathrm{Kin}(0.25,0.5,0.75$ and $1.0 \mathrm{mg} / \mathrm{l})$ for shoot multiplication. At the end of the experiment, percentage of shooting, shoot length and the number of shoots per explants were recorded. After six weeks, the micro shoots were transferred to rooting medium.

\subsubsection{Root proliferation:}

The healthy shootlets were transferred to half strength MS basal medium supplemented with individual concentrations of IBA $(0.25,0.50$ and $0.75 \mathrm{mg} / \mathrm{l})$ for root initiation. The percentage of rooting, root length and the number of roots per individual shoots were recorded.

\subsection{Determination of essential oil chemical composition}

The chemical composition was performed using Trace GC1310-ISQ mass spectrometer (Thermo Scientific, Austin, TX, USA) with a direct capillary column TG-5MS (30 m x $0.25 \mathrm{~mm}$ x $0.25 \mu \mathrm{m}$ film thickness). The column oven temperature was initially held at $50 \mathrm{C}$ and then increased by $5^{\circ} \mathrm{C} / \mathrm{min}$ to $230^{\circ} \mathrm{C}$ hold for $2 \mathrm{~min}$. increased line temperatures were kept at $250,260^{\circ} \mathrm{C}$ respectively; Helium was used as a carrier gas at a constant flow rate of $1 \mathrm{ml} / \mathrm{min}$. The solvent delay was $3 \mathrm{~min}$ and diluted samples of $1 \mu \mathrm{l}$ were injected automatically using Autosampler AS1300 coupled with GC in the split mode. EI mass spectra were collected at $70 \mathrm{eV}$ ionization voltages over the range of $\mathrm{m} / \mathrm{z} 40-1000$ in full scan mode. The ion source temperature was set at $200{ }^{\circ} \mathrm{C}$. The components were identified by comparison of their retention times and mass spectra with those of WILEY 09 and NIST 11 mass spectral database.

\subsection{Agrobacterium culture and transformation strain}

Agrobacterium tumefaciens strain LBA 4404 harboring a binary vector (pRI 101 - on DNA Grx2) was used for plant transformation experiment which was introduced into A. tumefaciens according to the method of Tzfira et al. (1997). The binary vector consisted of the Glutaredoxin-2 target gene (Grx-2), which was cloned from Cyan bacterium synechocystis PCC 6803, under the control of cauliflower mosaic virus $35 \mathrm{~S}$ (CaMV 35S) promoter and nopaline synthase (nos) terminator, and the selective Kanamycin resistance gene npt I. Explants were basely trimmed and $\sim 1.0 \mathrm{~cm}$ vertically cultured on MS- medium (Murashig and Skoog, 1962), (MS + $30 \mathrm{~g} / \mathrm{l}$ sucrose $+3.0 \mathrm{mg} / \mathrm{l} \mathrm{BA}+7 \mathrm{~g} / \mathrm{l}$ agar ) then were cultured in glass jars, culture explants were incubated for 4 weeks under controlled conditions, micro nodes of proliferated shootlets from Ocimum citriodorum immersion in liquid MS medium with 50, 100 and $150 \mu \mathrm{M}$ acetosyringone for 30 and $60 \mathrm{~min}$ in tissue culture tubes (Wang et al., 2010). The successful cultured explants from the previous treatments were basely wounded and subjected to transformation experiment, immersed in the bacterial suspension in Petri dishes and inoculated for different periods $(0,15,30,60$ and $120 \mathrm{~min})$ with gentle agitation to increase the transformation rate micro nodes were then dried on sterile filter paper and cultured on regeneration MS medium (MS $+30 \mathrm{~g} / \mathrm{l}$ sucrose $+3.0 \mathrm{mg} / \mathrm{l} \mathrm{BA}+7 \mathrm{~g} / \mathrm{l}$ agar ) supplemented with $500 \mathrm{mg} / \mathrm{l}$ cefotaxime, and incubated in the growth room for 2-3 days in darkness without Kanamycin sulfate (Kan). After 2-3 days, micro nodes were transferred on the same fresh regeneration medium (MS $+30 \mathrm{~g} / 1$ sucrose + $3.0 \mathrm{mg} / \mathrm{l} \mathrm{BA}+7 \mathrm{~g} / \mathrm{l}$ agar) supplemented with $100 \mathrm{mg} / \mathrm{L} \mathrm{Kanamycine} \mathrm{and} 500 \mathrm{mg} / \mathrm{L}$ cefotaxim for selection, then incubated at $25^{\circ} \mathrm{C}$ under $16 \mathrm{~h} /$ day photoperiod of $40 \mu \mathrm{E} \mathrm{cm} \mathrm{S}$ for one month.

Survived shootlets were separated and transferred to MS medium supplemented with (MS + 30 $\mathrm{g} / \mathrm{l}$ sucrose $+3.0 \mathrm{mg} / \mathrm{BA}+7 \mathrm{~g} / \mathrm{l}$ agar) for 4 weeks under the same controlled condition, multiple shoots tips regenerated on this medium were than separated and sub-culture in the same medium every 2 weeks for further proliferation, once shoot were obtained, they were transferred to the shoot elongation medium.

The transformation efficiency based on the effect of inoculation period with A. tumefaciens on O. citrodurm different characters, calculated using diagnosis of DNA PCR results, as well as GC MS for volatile oil. Vegetative growth was based on survival percentage, number of shootlets/explant, shootlets height, number of leaves/ explant, root length of plantlets from successfully transformed plantlets. Agrobacterium transformation and regeneration of putative transformation various factors affecting the transformation efficiency: infection duration time was tested in this study. 


\subsection{DNA isolation and PCR}

Fresh leaves samples were collected from putatively transformed and non-transformed (control) plants. The DNA extraction was performed using DNeasy plant Mini Kit (QIAGEN). Genomic of extracted DNA was analyzed by polymerase chain reaction (PCR). PCR analysis was performed on the isolated DNA to amplify a $281 \mathrm{bp}$ fragment of the GRX2 by using specific primers, ssr $2061 \mathrm{~F}$ ( 5 AAGCGTTCATATGGCTGT CT 3), and ssr 2061 R(5 CTAACT ATGGAG CAGGG GGT3).

\subsection{PCR amplification}

PCR amplification was performed as described above (the PCR program to GRX-2 gene). The DNA bands were visualized on ultraviolet (UV) Trans illuminator and photographed with gel documentation system.Grx2 was used as a positive control template while the wild-type genomic DNA obtained from species served as a negative control. The PCR reaction was performed in a $20 \mu 1$ reaction mixture containing $40 \mathrm{ng}$ DNA templates, 10 pmole of each forward and reverse primers, $10 \mu \mathrm{l}$ of $2 \mathrm{X}$ power Taq PCR master mix (Biotecke Corporation) and volume was completed to $20 \mu \mathrm{l}$ using sterilized distilled water. The PCR program were as follows: $94{ }^{\circ} \mathrm{C}$ for $5 \mathrm{~min}$ followed by 35 cycles of $94{ }^{\circ} \mathrm{C}$ for $1 \mathrm{~min}, 58{ }^{\circ} \mathrm{C}$ for $1 \mathrm{~min}$ and $72{ }^{\circ} \mathrm{C}$ for $1 \mathrm{~min}$, and a final $7 \mathrm{~min}$ extension at $72{ }^{\circ} \mathrm{C}$.

\subsection{Data and parameters}

The treatment divided into three replicates, each replicate containing three explants in the jar. The experiment designed by Complete Randomized Design (CRD) and using LSD at $5 \%$ to compare the means of treatments (Steel and Torrie, 1980). The data analyzed by Co-State software Version-4 (Statistical Graphics Corporation, 1999).

\section{Results and Discussion}

\subsection{In vitro preparation}

\subsubsection{Disinfecting seeds}

Surface sterilization of seeds is a compulsory pre-requisite technique for seedling production to reduce the contamination and germinate dormant seeds. Various concentrations of different surface sterilization agent and time of treatment were presented in Table 1. The results of ANOVA indicated that the effect of seed sterilization treatment was significant $(p<0.01)$ on Decontamination and Germination Percentage (DP and GP). The best effect of disinfecting treatments was observed on decontamination percentage $(81 \%)$ for Sodium Hypochlorite for 10 min. Similarly, the maximum percentage of germination (66.66 \%) was observed at $10 \%$ Sodium Hypochlorite for $10 \mathrm{~min}$ and the minimum effect $(32.09 \%$ ) was found at $0.1 \%$ Mercuric Chloride for $15 \mathrm{~min}$.

Table 1: Effect of commercial bleach, mercuric chloride (MC) concentrations and immersion time on disinfecting of lemon basil seeds.

\begin{tabular}{lcc}
\hline Disinfectant substance & $\begin{array}{c}\text { Decontamination rate } \\
(\mathbf{\%})\end{array}$ & $\begin{array}{c}\text { Seed germination } \\
(\mathbf{\%})\end{array}$ \\
\hline Sodium hypochlorite $(20 \%$ for $5 \mathrm{~min})$ & $43.22 \mathrm{~b}$ & $33.33 \mathrm{~b}$ \\
Sodium hypochlorite $(10 \%$ for $10 \mathrm{~min})$ & $81.00 \mathrm{a}$ & $66.66 \mathrm{a}$ \\
Sodium hypochlorite $(5 \%$ for $20 \mathrm{~min})$ & $50.00 \mathrm{~b}$ & $11.11 \mathrm{~d}$ \\
Mercurric chloride $\quad(0.1 \%$ for $15 \mathrm{~min})$ & $32.09 \mathrm{~b}$ & $22.22 \mathrm{c}$ \\
Mercurric chloride $\quad(0.2 \%$ for $10 \mathrm{~min})$ & $81.00 \mathrm{a}$ & $22.22 \mathrm{c}$ \\
Mercurric chloride $\quad(0.3 \%$ for $5 \mathrm{~min})$ & $55.00 \mathrm{~b}$ & $6.66 \mathrm{e}$ \\
\hline LSD at 5\% & 26.17 & 4.238 \\
\hline
\end{tabular}

Bleaching activity of Mercuric Chloride $\left(\mathrm{HgCl}_{2}\right)$ due to chloride atoms as well as ions that can attach toughly with proteins and causing the death of organisms Pattnaik and Chand (1996). Sodium hypochlorite was successfully used in our study on lemon basil seeds with high percentage of seed germination and uniform growth of seedlings. The reports of (Baiyeri and Mbah, 2006; Newman, et al., 1996 and Moghaieb, et al., 2004) also proved the role of sodium hypochlorite as an efficient surface sterilization agent. Increasing time and concentration of $\mathrm{HgCl}_{2}$ and $\mathrm{NaOCl}$ significantly reduced the contamination and also affected the germination of seeds. For instance, develop shoot and leaf tips of 
O. sanctum were washed with savlon (1\%) and sterile distilled water for 20 minutes before the sterilization process (Banu and Bari, 2007) and axillary buds from O. basilicum, O. americanum, $O$. sanctum and $O$. gratissimum were washed for 5 minute in sodium hypochlorite and laboline solution, then water rinse before disinfecting (Mandal et al., 2000). Also, Pattnaik and Chand (1996) used axillary buds of $\mathrm{O}$. sanctum, $O$. americanum, and $O$. canum and only did a prewash with water before applying the surface sterilization with a combination of sodium hypochlorite $(\mathrm{NaOCl} 10.5 \% \mathrm{v} / \mathrm{v})$, sodium hydroxide $(\mathrm{NaOH} 0.5 \%, \mathrm{w} / \mathrm{v})$, sodium chloride $(\mathrm{NaCl} 10 \%, \mathrm{w} / \mathrm{v})$ and sodium carbonate $(\mathrm{Na} 2 \mathrm{CO} 30.3 \%$, $\mathrm{w} / \mathrm{v})$ for 10 minutes and finally washing the explants several times by sterile distilled water. On the other hand, Xiong et al. (2009) employed a 30 minute prerinse in distilled water, followed by a $25 \%$ clorox solution for 10 minutes for sterilizing and culturing the leaves of $O$. sanctum on the initiation medium. Jamal et al. (2016) observed practically feasible surface disinfection for explants of $O$. sanctum with using $\mathrm{HgCl} 2(0.1 \% \mathrm{w} / \mathrm{v})$ for $7 \mathrm{~min}$. or $\mathrm{NaOCl}(1 \% \mathrm{v} / \mathrm{v})$. What's more, they showed that the nodal explants are more suitable to micropropagation than the shoot tips. Besides that, young leaf explants from $O$. basilicum at different development stages (cotyledons, petioles and stems) were service sterilized with 20\% bleach (Clorox) for 20 min (Phippen and Simon, 2000).

Also, Pasqual et al., (2012) found the basil seeds were disinfested in $70 \%$ ethanol $\left(\mathrm{v} \mathrm{v}^{-1}\right)$ for one minute followed by immersion in a solution of sodium hypochlorite $30 \%\left(\mathrm{v} \mathrm{v}^{-1}\right)$ for 20 min. Subsequently, in a laminar air flow hood, seeds were rinsed three times with sterile distilled water and inoculated in MS medium with or without activated charcoal and supplemented with $\mathrm{GA}_{3}(0.0,0.5,1.0$ or $\left.1.5 \mathrm{mg} \mathrm{L}^{-1}\right)$ as well as inoculated in MS medium with two ionic concentrations (50 or $100 \%$ ) supplemented with three sucrose concentrations $\left(10,20\right.$ or $\left.30 \mathrm{~g} \mathrm{~L}^{-1}\right)$.

The different system for seed surface sterilization and time of immersion not only has effect on the uniform growth of seedlings, but also affects the Germination Percentage. Hence, in our study, using $10 \%$ Sodium Hypochlorite for 10 min was more suitable surface sterilization agent and uniformity growth of seedlings in lemon basil.

\subsubsection{Shootlet proliferation}

Data of the effectiveness of various media to improving better growth media for ideal explants production in respect of Shootlet number (SN), Shootlet length (SL) and Leaves number (LN) were given in Table 2. The highest rate of Shootlet number (SN); Shootlet Length (SL) and Leaves number (LN) were obtained in case of MS medium with $3 \mathrm{mg} / 1 \mathrm{BAP}$, while the lowest were observed on control.

Table 2: Effect of plant growth regulators on growth characterization of lemon basil seedling in vitro.

\begin{tabular}{|c|c|c|c|c|}
\hline Media code & Media contents & $\begin{array}{c}\text { Shoot } \\
\text { No. }\end{array}$ & $\begin{array}{l}\text { Shoot } \\
\text { Length }\end{array}$ & $\begin{array}{c}\text { Leaves } \\
\text { No }\end{array}$ \\
\hline M0 & $\mathrm{MS}+30 \mathrm{~g}$ sucrose $+7 \mathrm{~g} / \mathrm{l}$ agar & 1.01 & 1.45 & 5.32 \\
\hline M1 & $\mathrm{MS}+30 \mathrm{~g}$ sucrose $+7 \mathrm{~g} / \mathrm{lagar}+1.0 \mathrm{BAP}$ & 2.81 & 4.07 & 7.76 \\
\hline M2 & $\mathrm{MS}+30 \mathrm{~g}$ sucrose $+7 \mathrm{~g} / 1 \mathrm{agar}+2.0 \mathrm{BAP}$ & 5.23 & 5.23 & 13.54 \\
\hline M3 & $\mathrm{MS}+30 \mathrm{~g}$ sucrose $+7 \mathrm{~g} / 1$ agar $+3.0 \mathrm{BAP}$ & 8.12 & 9.12 & 17.45 \\
\hline M4 & $\mathrm{MS}+30 \mathrm{~g}$ sucrose $+7 \mathrm{~g} / \mathrm{lagar}+0.1 \mathrm{BAP}$ & 3.28 & 3.75 & 13.71 \\
\hline M5 & $\mathrm{MS}+30 \mathrm{~g}$ sucrose $+7 \mathrm{~g} / \mathrm{lagar}+0.2 \mathrm{BAP}$ & 1.98 & 4.56 & 11.05 \\
\hline M6 & $\mathrm{MS}+30 \mathrm{~g}$ sucrose $+7 \mathrm{~g} / 1$ agar $+0.3 \mathrm{BAP}$ & 2.34 & 4.76 & 12.67 \\
\hline M7 & $\mathrm{MS}+30 \mathrm{~g}$ sucrose $+7 \mathrm{~g} / \mathrm{lagar}+1.0 \mathrm{BAP}+0.1 \mathrm{Kin}$ & 2.56 & 6.08 & 11.17 \\
\hline M8 & $\mathrm{MS}+30 \mathrm{~g}$ sucrose $+7 \mathrm{~g} / \mathrm{l}$ agar $+1.0 \mathrm{BAP}+0.2 \mathrm{Kin}$ & 2.33 & 4.43 & 10.14 \\
\hline M9 & $\mathrm{MS}+30 \mathrm{~g}$ sucrose $+7 \mathrm{~g} / 1$ agar $+1.0 \mathrm{BAP}+0.3 \mathrm{Kin}$ & 1.98 & 6.28 & 12.97 \\
\hline M10 & $\mathrm{MS}+30 \mathrm{~g}$ sucrose $+7 \mathrm{~g} / 1$ agar $+2.0 \mathrm{BAP}+0.1 \mathrm{Kin}$ & 3.78 & 4.96 & 11.30 \\
\hline M11 & $\mathrm{MS}+30 \mathrm{~g}$ sucrose $+7 \mathrm{~g} / \mathrm{l}$ agar $+2.0 \mathrm{BAP}+0.2 \mathrm{Kin}$ & 2.17 & 5.69 & 10.72 \\
\hline M12 & $\mathrm{MS}+30 \mathrm{~g}$ sucrose $+7 \mathrm{~g} / \mathrm{l} \mathrm{agar}+2.0 \mathrm{BAP}+0.3 \mathrm{Kin}$ & 2.01 & 5.19 & 16.93 \\
\hline M13 & $\mathrm{MS}+30 \mathrm{~g}$ sucrose $+7 \mathrm{~g} / 1$ agar $+3.0 \mathrm{BAP}+0.1 \mathrm{Kin}$ & 1.21 & 5.80 & 11.37 \\
\hline M14 & $\mathrm{MS}+30 \mathrm{~g}$ sucrose $+7 \mathrm{~g} / \mathrm{l}$ agar $+3.0 \mathrm{BAP}+0.2 \mathrm{Kin}$ & 3.76 & 5.46 & 11.02 \\
\hline M15 & $\mathrm{MS}+30 \mathrm{~g}$ sucrose $+7 \mathrm{~g} / \mathrm{lagar}+3.0 \mathrm{BAP}+0.3 \mathrm{Kin}$ & 2.12 & 3.77 & 13.43 \\
\hline LSD $5 \%$ & & 0.680 & 1.649 & 4.981 \\
\hline
\end{tabular}

Our findings showed MS medium with $3 \mathrm{mg} / \mathrm{l} \mathrm{BAP}$ has better response in terms of average of shoot length $(9.12 \mathrm{~cm})$. Maximum value of shootlet number $(8.12)$ was achieved by same concentration 
of BAP (3 mg/l) in MS medium. As it is described in Table 2, analysis of data indicated that the effect of BAP was significant $(\mathrm{p}<0.01)$ on leaves number $(17.45)$ as well as the mean growth indicator.

For shoot initiation, Saha et al. (2010) cultured excised nodal fragments $(1-1.2 \mathrm{~cm})$ from $O$. basilicum on Murashige and Skoog (1962) basal medium containing 3\% (w/v) sucrose and $\mathrm{pH}$ of 5.7 before gelling with $0.8 \%(\mathrm{w} / \mathrm{v})$ agar. The explants were planted vertically on the growth medium in test tube $(150 \times 25 \mathrm{~mm})$ and closed firmly with non-absorbent cotton. Also, Mishra (2015) cut the sanitized young leaves of $\mathrm{O}$. sanctum into $5 \mathrm{~mm}$ x $5 \mathrm{~mm}$ squares and these explants were immunized on MS basal medium for the same objective.

\subsubsection{Root induction}

Data observed in Table (3) recorded the effect of IBA concentrations in combination with kin and BAP, the best effect was observed with explant treated with IBA at $0.75 \mathrm{mg} / \mathrm{l}$ plus kin at $0.75 \mathrm{mg} / \mathrm{l}(100$ $\%)$ rooting followed by the same concentration of IBA followed by the little concentration of kin $(0.50$ $\mathrm{mg} / \mathrm{l})$. The previous treatments scored highly average of roots count (20.12 root/shootlet) with longest length of roots $5.09 \mathrm{~cm}$.

Table 3: Effect of various concentrations of BAP, Kin and IBA on roots characterization

\begin{tabular}{|c|c|c|c|}
\hline PGRs Treatments & Rooting \% & Root No. & Root length \\
\hline Control & 100 & 2.11 & 0.43 \\
\hline BAP at $0.25+$ IBA 0.25 & 11.11 & 3.12 & 0.67 \\
\hline $\mathrm{BAP}$ at $0.25+$ IBA 0.50 & 11.11 & 4.17 & 1.23 \\
\hline BAP at $0.25+$ IBA 0.75 & 100 & 12.12 & 1.34 \\
\hline $\mathrm{BAP}$ at $0.50+\mathrm{IBA} 0.25$ & 33.33 & 11.20 & 1.65 \\
\hline BAP at $0.50+$ IBA 0.50 & 0.00 & 0.00 & 2.33 \\
\hline BAP at $0.50+$ IBA 0.75 & 100 & 13.21 & 1.23 \\
\hline BAP at $0.75+$ IBA 0.25 & 33.33 & 9.17 & 2.03 \\
\hline $\mathrm{BAP}$ at $0.75+$ IBA 0.50 & 88.89 & 10.22 & 1.02 \\
\hline BAP at $0.75+$ IBA 0.75 & 0.00 & 0.00 & 0.00 \\
\hline Kin at $0.25+$ IBA 0.25 & 77.78 & 10.12 & 2.04 \\
\hline Kin at $0.25+$ IBA 0.50 & 100 & 14.21 & 2.19 \\
\hline Kin at $0.25+$ IBA 0.75 & 22.22 & 8.09 & 1.09 \\
\hline Kin at $0.50+$ IBA 0.25 & 0.00 & 0.00 & 0.00 \\
\hline Kin at $0.50+$ IBA 0.50 & 100 & 11.27 & 3.43 \\
\hline Kin at $0.50+$ IBA 0.75 & 11.11 & 8.01 & 3.09 \\
\hline Kin at $0.75+$ IBA 0.25 & 100 & 12.45 & 4.82 \\
\hline Kin at $0.75+$ IBA 0.50 & 100 & 17.22 & 4.61 \\
\hline Kin at $0.75+$ IBA 0.75 & 100 & 20.12 & 5.09 \\
\hline L.S.D $5 \%$ & 30.54 & 2.126 & 1.928 \\
\hline
\end{tabular}

Singh and Seghal (1999) observed direct regeneration and multiple shoot induction incubating $O$. sanctun inflorescences on MS containing 0,5 to $3,0 \mathrm{mg} \cdot \mathrm{L}^{-1}$ of BAP. In their studies, the medium containing $1 \mathrm{mg} . \mathrm{L}^{-1}$ of BAP and 0,05 proved to be most effective. Several authors have observed a strong co-relation between the auxin/citokinin ratio in the media and shoot formation using different explant sources and genotypes (Pattnaik and Chand, 1996; Khanna and Raina, 1998; Singh and Sehgal, 1999; Shahzad and Siddiqui, 2000). Phippen and Simon (2000) used high cytokinin levels to successfully stimulate leaf organogenesis in basil. However, the tested media were not proper to stimulate shoot regeneration from cotyledons, petioles or stems.

\subsection{GC - MS of Essential oil}

The results from the quantitative and qualitative analysis of essential oils constituents are presented in Table 4 the average yield of the essential oils was $0.2 \%$.

More than 38 compounds were isolated, detected and most of them were identified for essential oil sample. The dominant components were identified to be linalool, methyl chavicol and Eugenol. According to data in Table 4 lists the compounds that identified by GC-MS in the essential oil of lemon basil. A total of 38 compounds were detected for O. citriodorum, representing $99.2 \%$ of the total compounds in essential oil (Table 4). 

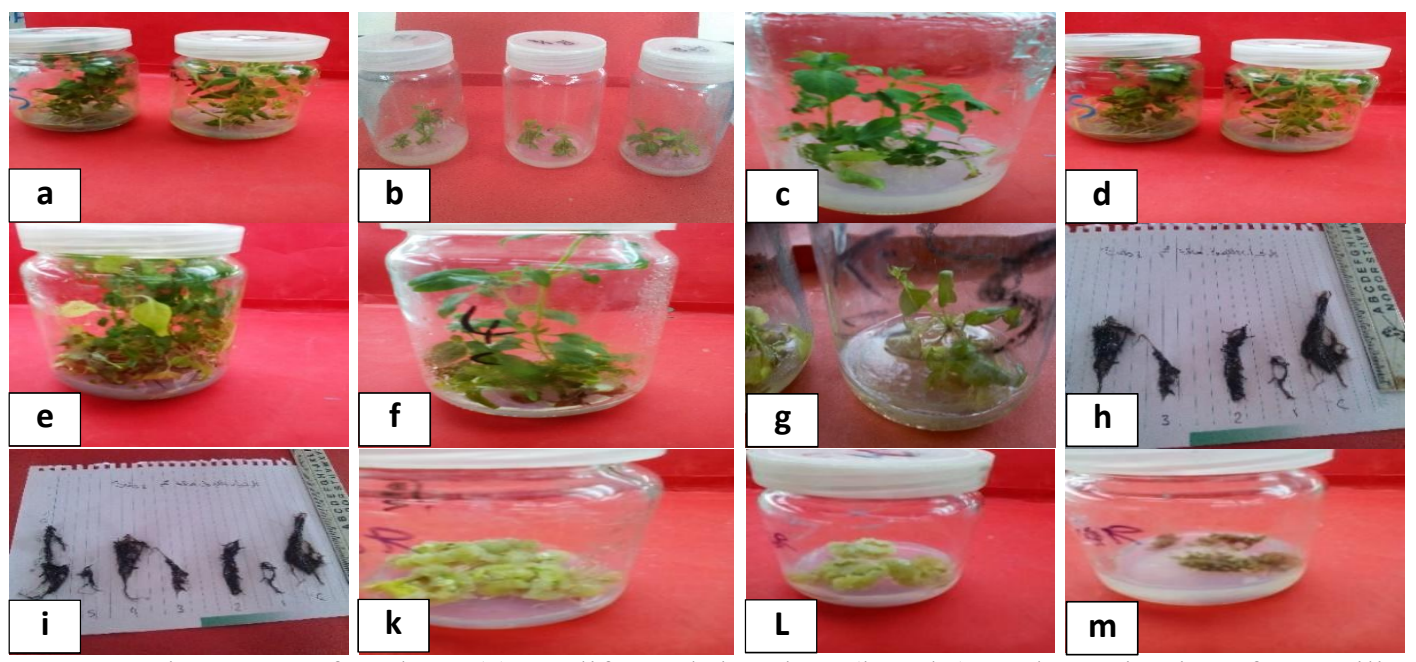

Fig. 1: Various parts of explants (a): proliferated shootlets; (b and c) seed germination after sterilization; $(\mathrm{d}, \mathrm{e}, \mathrm{f})$ shootlets elongation and proliferated; $(\mathrm{g}, \mathrm{h}, \mathrm{i})$ root induction and root length and $(\mathrm{k}, \mathrm{l}$ and $\mathrm{m})$ callogenesis from root, stem and leaves (data not show)

Despite the qualitative and quantitative differences between the composition of the oil contents, linalool was found to be the major (43.415\%) compound in the oil sample followed by eugenol, which presented also a very high amount $(19.689 \%)$, and methyl - chavecoal $(7.075 \%), \alpha$-pinene $(4.818 \%)$, myrcene (4.083\%), $\beta$-pinene (3.51\%), $\alpha$-pinene-4-ol (2.091\%), $\alpha$-terpineol (2.83 \%), geraniol (2.311 $\%)$, $\beta$ - Caryophyllene $(2.113 \%)$ and cis- $\beta$-Farnesene $(1.368 \%)$. Considering relative percentages, lemon basil presented a higher content of oxygenated monoterpenes and of sesquiterpenes. When compared to previously reported data, the profile of $O$. basilicum cultivar 'Cinnamon' was very similar to that described by Wesolowska and Jadczak (2016) regarding the same cultivar cultivated in Northwestern Poland, but completely distinct to that reported by Tsasi et al. (2017). The chemical profile of O. basilicum cultivar 'Cinnamon' samples collected in the Island of Kefalonia, Greece, showed methyl chavicol as major compound (ranging from $60.2-75.1 \%)$ followed by linalool $(0.6-5.7 \%$ ) and germacrene D (3.2-5.0\%), while in the present study the content of methyl chavicol was much lower (2.5\%). According to Vieira and Simon (2006) who studied the volatile profile of different basil species, $O$. basilicum cv. 'Cinnamon' can be differentiated from three other Ocimum species $(O$. americanum, $O$. $\times$ citriodorum and $O$. minimum) and 14 O. basilicum cultivars by the high amount of (E)-methylcinnamate, which is in good agreement with the data reported by Wesolowska and Jadczak (2016) and the present study. These data are in a good accordance with the results reported by Sishu et al. (2010). For the essential oil from $O$. x citriodorum species the predominant constituents were identified to be citral (21\%) and nerol (23\%), therefore it could not be classified as belonging to any of the chemotypes mentioned above, but will rather form its own, nerol-rich chemotype. Data on $O$. x citriodorum are somewhat consistent with the similar results published by Carovic-Stanko et al. (2010) on essential oil distilled from the plant of the same species, except for the fact that there were more than 45 constituents of $O$. x citriodorum essential oil identified in the present study, as opposed to 20 components identified by Carovic-Stanko (2010).

\subsection{Integration and expression of the $G R X-2$ gene in transgenic plantlets 3.3.1. Morphological characters}

Many methods of ocimum transformation are tissue culture based, requiring regeneration of whole plants from transformed cells. The utility of the techniques greatly depends on the establishment of tissue culture protocols in the species. Tissue culture is labor intensive and can be difficult. In addition, even under optimal transformation and regeneration conditions, tissue culture can result in somaclonal variation, morphological abnormalities, changes in chromosome number, and loss of fertility (Noguera et al., 2005). The development tissue culture independent transformation system is of great interest because such a system would avoid constraints imposed by genotype specificity in 
transformation and regeneration and avoid tissue culture induced genetic variation. In addition, transgenic plants would be produced inexpensively and rapidly.

Table 4: Chemical composition of essential oils of in vitro explants of Ocimum citriodorum

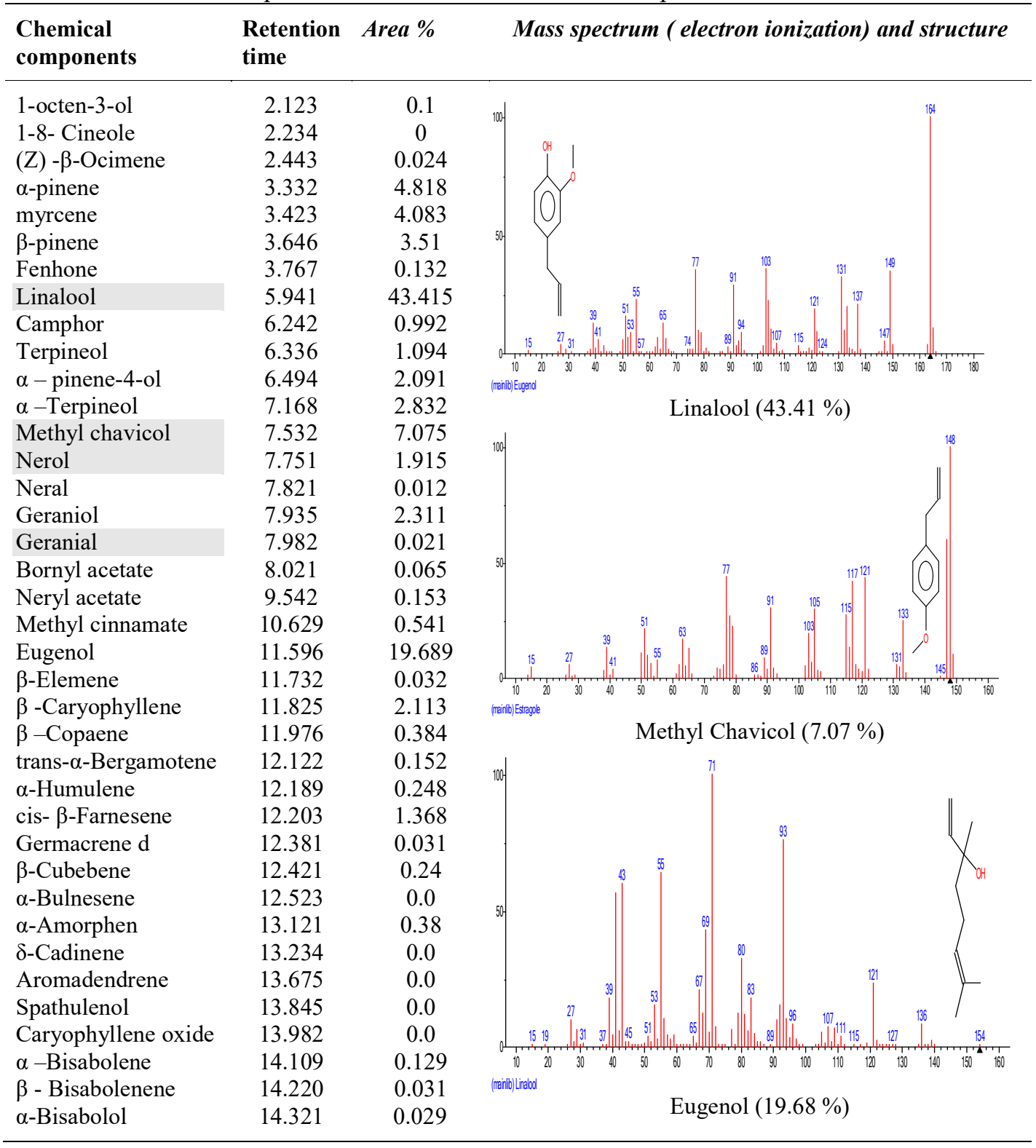

According to data in Table 5. and Fig. 2 the explants immersion in acetosyringone were survived at highest percentage $66.66 \%$ after treated with acetosyringone $150 \mu \mathrm{M}$ for 60 min followed by the same concentration at $30 \mathrm{~min} 33.33 \%$ and $60 \mathrm{~min}$ at $100 \mu \mathrm{M}$. Moreover, the successful explants from acetosyringone treatments $(150 \mu \mathrm{M}$ for $60 \mathrm{~min})$ were wounded and infected with a single cell culture of $A$. tumeficiens strain LBA4404 carrying the GRX-2 and nptII genes in the pRI 101-ON DNA plasmid vector by immersion at 15, 30,60 and $120 \mathrm{~min}$ in the liquid medium cultured on MS selective medium containing $500 \mathrm{mg} / \mathrm{l}$ Cefotaxim for 2-3 day.

At the end of inoculation period (2-3 days) the explants were re-cultured on MS medium containing kanamycin $100 \mathrm{mg} / \mathrm{l}$ and cefotaxime $500 \mathrm{mg} / \mathrm{l}$ and incubation for four weeks.

Data in Table (6) showed the explants growth characters were observed after incubation period (4 weeks), wherever, the explants exposed to Agrobacterium solution for $60 \mathrm{~min}$ gave the highest 
percentage of survival (100\%) compared with other treatments except with untreated explants (control) $100 \%$. Shoot length of transgenic plant was $1.1 \mathrm{~cm}$ with 2.3 shootlet/plant with 3.4 leaves per shootlet compared with all treatments except of non-transgenic explants (control).

Table 5: Effect of acetosyringone concentrations and time of immersion on survival percentage of transgenic micro-nodes of lemon basil

\begin{tabular}{lcc}
\hline \multicolumn{2}{l}{ Acetosyringone concentrations / time } & Survival \% \\
\hline $\mathbf{5 0} \boldsymbol{\mu M}$ acetosyringone & $\mathbf{3 0} \mathbf{~ m i n}$ & $00.00 \mathrm{c}$ \\
& $\mathbf{6 0} \mathbf{~ m i n}$ & $00.00 \mathrm{c}$ \\
$\mathbf{1 0 0} \boldsymbol{\mu M}$ acetosyringone & $\mathbf{3 0} \mathbf{~}$ in & $00.00 \mathrm{c}$ \\
& $\mathbf{6 0} \mathbf{~ i n}$ & $33.33 \mathrm{~b}$ \\
$\mathbf{1 5 0} \boldsymbol{\mu M}$ acetosyringone & $\mathbf{3 0} \mathbf{~ m i n}$ & $33.33 \mathrm{~b}$ \\
& $\mathbf{6 0} \mathbf{~ m i n}$ & $66.66 \mathrm{a}$ \\
\hline LSD at $\mathbf{5 \%}$ & & 9.0732 \\
\hline
\end{tabular}
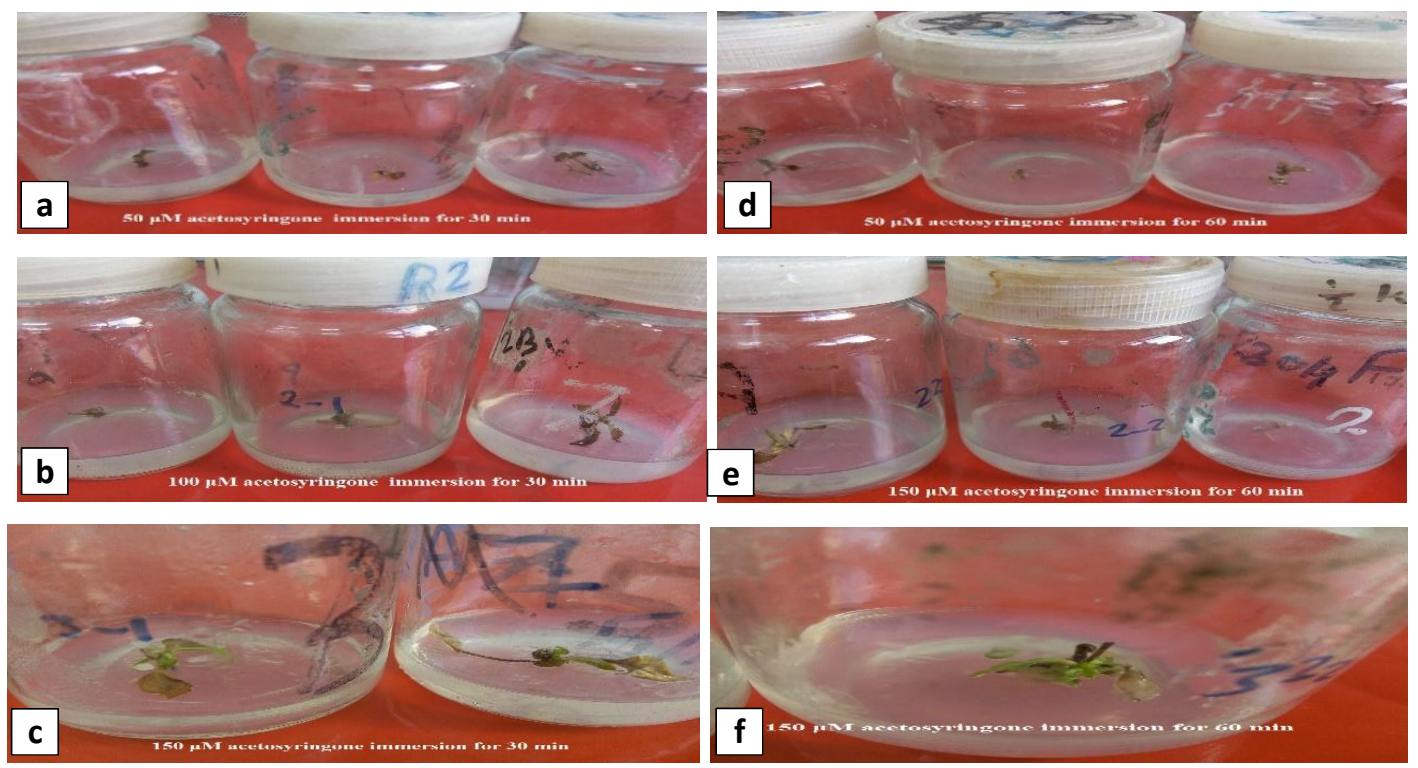

Fig. 2: Effect of acetosyringone concentrations and time of immersion on survival percentage and transformation frequency, a,b and c: 50, 100 and $150 \mathrm{uM}$ for $30 \mathrm{~min}, \mathrm{c}, \mathrm{d}$ and $\mathrm{f}: 50,100$ and $150 \mathrm{uM}$ for $60 \mathrm{~min}$.

Data indicated that explants micronodes used stable for lemon basil regeneration this was found to be in agreement with Nadel, et al. (1992) that micronodes inoculated with A.tumefaciens suspension $(\mathrm{OD} 600=0.8)$ for $20 \mathrm{~min}$. and grown in selective medium which contain $100 \mathrm{mg} / \mathrm{l}(\mathrm{kan})$ got the highly transformation frequency, similarly with previous studies by (Confalonieri et al. 2000, Bansal et al. 2008, Han et al. 2013 and Movahedi et al. 2014). Transformation efficiency might also be influenced by the co cultivation time between explants and Agrobacterium according to the studies of (Rutledge and Douglas, 1988 and De Block 1990). The explants that were pre-cultured for 3 days survived the infection better accelerates the rate of T-DNA incorporation in cells by increasing their competence rather than increasing the rate of DNA transfer from Agrobacterium, allowing a greater survival of transformed cells that it in agreement with (Binns and Thomashow, 1988). Similar findings were observed in a variety of cottonwood species (De Block, 1990 and Balestrazzi et al, 2000; Han et al, 2000).

The regenerated shootlets derived from single bud explant was selected on MS medium containing Kanamycin as a selective agent (Fig. 3). In order to test that T0 plants carrying GRX-2 and npt-II genes in their tissue, total genomic DNA was purified from T0 plant tissues and subjected for PCR analysis using GRX-2 and npt-II genes primers. 


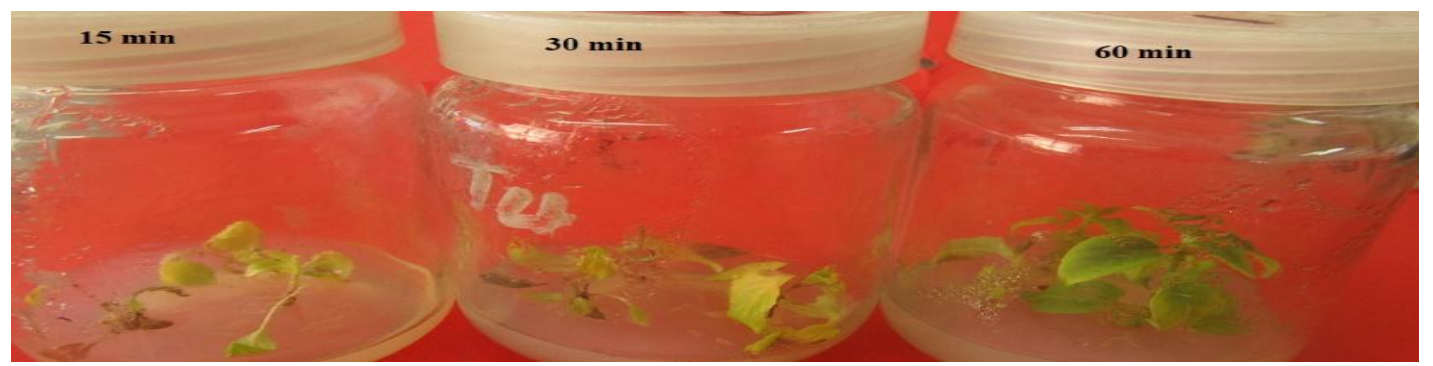

Fig. 3: Agrobacterium-infected lemon basil micro-node after immersion for 15, 30 and $60 \mathrm{~min}$ in bacterial suspension

Table 6: Morphological characterization of $G R X-2$ transgenic basil explants after exposure to Agrobacterium tumifecient four time

\begin{tabular}{cccccc}
\hline & Survival \% & Shoot length (cm) & Shootlet No. & Leaves No. & Rooting \% \\
\hline $\mathbf{0} \mathbf{~ m i n}$ & 100 & 4.7 & 3.4 & 8.3 & 0.0 \\
$\mathbf{1 5} \mathbf{~ m i n}$ & 75.0 & 1.2 & 1.0 & 2.0 & 0.0 \\
$\mathbf{3 0} \mathbf{~ m i n}$ & 50.0 & 1.3 & 1.0 & 2.3 & 0.0 \\
$\mathbf{6 0} \mathbf{~ m i n}$ & 100 & 1.1 & 2.3 & 3.4 & 50.0 \\
$\mathbf{1 2 0} \mathbf{~ m i n}$ & 25.0 & 1.0 & 1.0 & 2.0 & 0.0 \\
\hline LSD 5\% & 22.198 & 0.918 & 0.834 & 1.231 & 11.11 \\
\hline
\end{tabular}

\subsubsection{PCR analysis}

The PCR results confirmed the presence of a DNA band of $281 \mathrm{bp}$ when $G R X-2$ primers were used (Fig. 4). This show that DNA purified from T0 regenerated plants carrying GRX2 gene that was transformed from the vector and it's transgenic plants, however, no amplification product was observed in untransformed plants. In order to calculate the transformation frequency in $\mathrm{T} 0$ plants, it was found that only 6 out of 18 putatively transformed plants were confirmed to be transgenic, representing a percentage of $33.3 \%$.

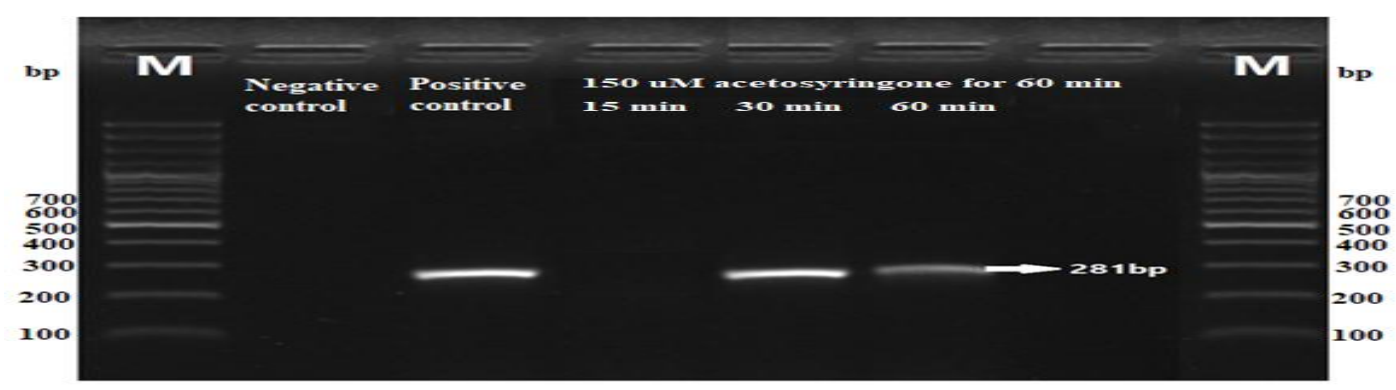

Fig. 4: Analysis of PCR of the GRX2 gene in DNA plants. Lane $1=$ ladder 700 bp. Lane $2=$ negative control consisting of non-transformed plant DNA. Lane $3=$ positive control consisting of the plasmid. Lanes 4, 5 and $6=$ represent plant exposure to bacteria suspension for 15,30 and 60 min after immersion in $150 \mathrm{uM}$ acetosyringone for $60 \mathrm{~min}$

The inheritance of the transgenes into the regenerated plants and confirmed by detection of $G R X$ 2 gene by PCR analysis employing $G R X-2$ primers as shown in Figs. 4. The presence of amplified 281 bp DNA bands from the genome of first subculture plants confirmed the integration of GRX-2 gene and its inheritance to subcultures and rooting stages generations. GRX, widely found in bacteria, plants, and mammalian cells, is an electron carrier for ribonucleotide reductase and a general glutathione-disulfide reductase of important for redox regulation. GRXs were previously described to have functions in controlling plant development, DNA synthesis, signaling and stress response, and [Fe-S] assembly (Cheng et al., 2006; Cheng, 2008 and Rouhier et al., 2004). Cyanobacterium Synechocystis strain PCC 6803 contains two genes GRX-1 and GRX-2 (Gaber et al., 2006 and Li et al., 2010). Gaber et al. (2006) studied the transcript level of GRX-2 in Synechocystis sp. PCC 6803 cell under different stress 
conditions, and cloned of the GRX-2 gene of Synechocystis sp. PCC 6803 in the cytoplasm of E. coli and found that the transformed E. coli cells showed high tolerance to $\mathrm{NaCl}$ (over than $700 \mathrm{mM}$ ). In this study, a GRX-2 gene from Synechocystis sp. PCC 6803 was synthesized and cloning in plant vector to introducing it to tomato plant. This is the first report for the development of transgenic tomato plants harboring salt tolerance gene, $G R X-2$. Results of this study indicated that $G R X-2$ plays a crucial role in salt stress and will provide useful information for studying the molecular mechanism of plant responses to environmental stresses and for genetically engineering of crops to improve their stress tolerance.

\subsubsection{Essential oil for transgenic explants}

After transformation explants were incubation on MS medium containing 3 BAP for 4 weeks, some hydrocarbons (Table 7) Propyl octanoate, Undecanoic acid, thiol compound Butane, 1-ethenylthio formed in the essential oil. Propyl octanoate $(0.12 \%)$, also known as propyl caprylate, belongs to the class of organic compounds known as fatty acid esters. These are carboxylic ester derivatives of a fatty acid. Racemic $\alpha$-campholenic aldehyde $(0.18 \%)$ by a catalytic rearrangement of optically active or racemic $\alpha$-pinene oxide that can be commercially practicable. P-Cymen $(2.16 \%)$; myrcene $(4.08 \%)$; limonene $(40.2 \%)$; linalool (17.73\%); camphor (3.03\%); $\alpha$-terpineol $(2.98 \%)$; methyl chavicol (2.58\%); geraniol (2.02\%); eucalyptol (1.54\%); eugenol $16.8 \%)$; and $\beta$-caryophyllene (2.4 \%) these compounds obtained from degradation some volatile compounds by activation GRX2 gene which responsible for enzymatically oxidation for some highly molecular weight compounds to hydrocarbon chains compounds and transformed to volatile compound.

The major terpenoids accumulating (Table 7 and Fig. 7) in lemon basil are linalool (43.5\%), eugenol $19.68 \%$, and methyl chavicol $7.07 \%$ (a mixture of geranial and neral). Lemon basil genes encoding various terpene synthase enzymes, including linalool synthase (LIS) and eugenol synthase (EGS), have been functionally characterized (Iijima et al. 2004a and Iijima et al. 2004b). The balance between linalool and eugenol in the different chemotypes was shown to be driven by differential expression levels of LIS and EGS genes, as well as by allelic variation (Iijima et al. 2004a).

In our study, after insertion GRX2 gene in lemon basil genome by Agrobacterium caused decreasing linalool from 43.5 to $17.73 \%$ that resulted by inhibition LIS enzyme which responsible to linalool synthesis. In this concern, A 1-bp insertion caused a premature stop codon in the LIS gene from the citral chemotypes in comparison to the LIS gene from the linalool chemotype (Iijima et al. 2004a). A certain degree of balance between the phenylpropanoid pathway and the terpenoid pathway was noticed in both transcriptional, proteomic, and enzymatic levels of the enzyme phenylalanine ammonia lyase (PAL). This evolutionary mechanism (converted eugenol-o-methyltransferase (EOMT) activity into chavicol-o-methyltransferase (CVOMT) activity) might provide the basis for methyl chavicol basil chemotypes.

Absence of chavicol-o-methyltransferase (CVOMT) activity might shift the metabolic flux toward eugenol synthesis as was observed between methyl chavicol accumulating lines and eugenol accumulating lines (Lewinsohn et al., 2000 and Gang et al. 2001). Methyl chavicol levels decreased in matured basil leaves, following the reduction of CVOMT gene expression and enzymatic activity (Deschamps et al. 2006).

Finally, this oil does not contain genetic material, because DNA is not volatile and remains in the basil hay residue. However, regulatory agencies in some countries require labeling of products of transgenic provenance. To enable the tracing of oil from transgenic basil plants it would thus be advantageous if it contained a chemical marker. Such a marker would have to be present at low levels in the oil, should be easily detectable by standard analytical methods, and should not affect the organoleptic properties of the oil.

The wild basil oils grown in various Egyptian locations contain readily detectable amounts of linalool in non-transgenic plant (43.415\% of the essential oil), the precursor to all p-menthane monoterpenes but only very small amounts (ranging between $0.07 \%$ and $0.25 \%$ of the essential oil) of its enantiomer, (+)-limonene (Mosandl et al., 1991).

The essential oil of basil is accumulated in its glandular trichomes located on the surface of the leaves (Werker et al. 1993 and Gang et al. 2001). The ability to isolate these trichomes and specifically check gene expression and enzymatic activities (Lewinsohn et al. 2000 and Iijima et al. 2004b) has enabled the characterization of important genes and enzymes in the biosynthetic pathways. Homologous genes or allelic variants may cause different metabolic profiles and can be utilized for breeding 
proposes. Two major groups of compounds compose basil aroma: (i) phenylpropanoids and (ii) terpenoids.

The Federal Drug Administration of the United States lists (+)-limonene under the chemicals with "generally recognized as safe" (GRAS) status and enhanced levels of (+)-limonene would thus be a highly suitable chemical marker for transgenic plants Hall and Oser, (1965). Identification of a gene that encodes a (+)-limonene synthase (PLS) would provide for such a marker gene.

At the end of this work, we recommended using tissue culture of lemon basil and transfer GRX2 gene by Agrobacterium tumefaciens increasing quantity of volatile oil compounds by activation enzymes responsible for enhance level of limonene in volatile oil and stable other compounds in the oil. Also, gave the plant some tolerant for salinity as showed in the previous studies.

Table 7: Chemical composition of essential oils of in vitro transgenic explants of Ocimum citriodorum

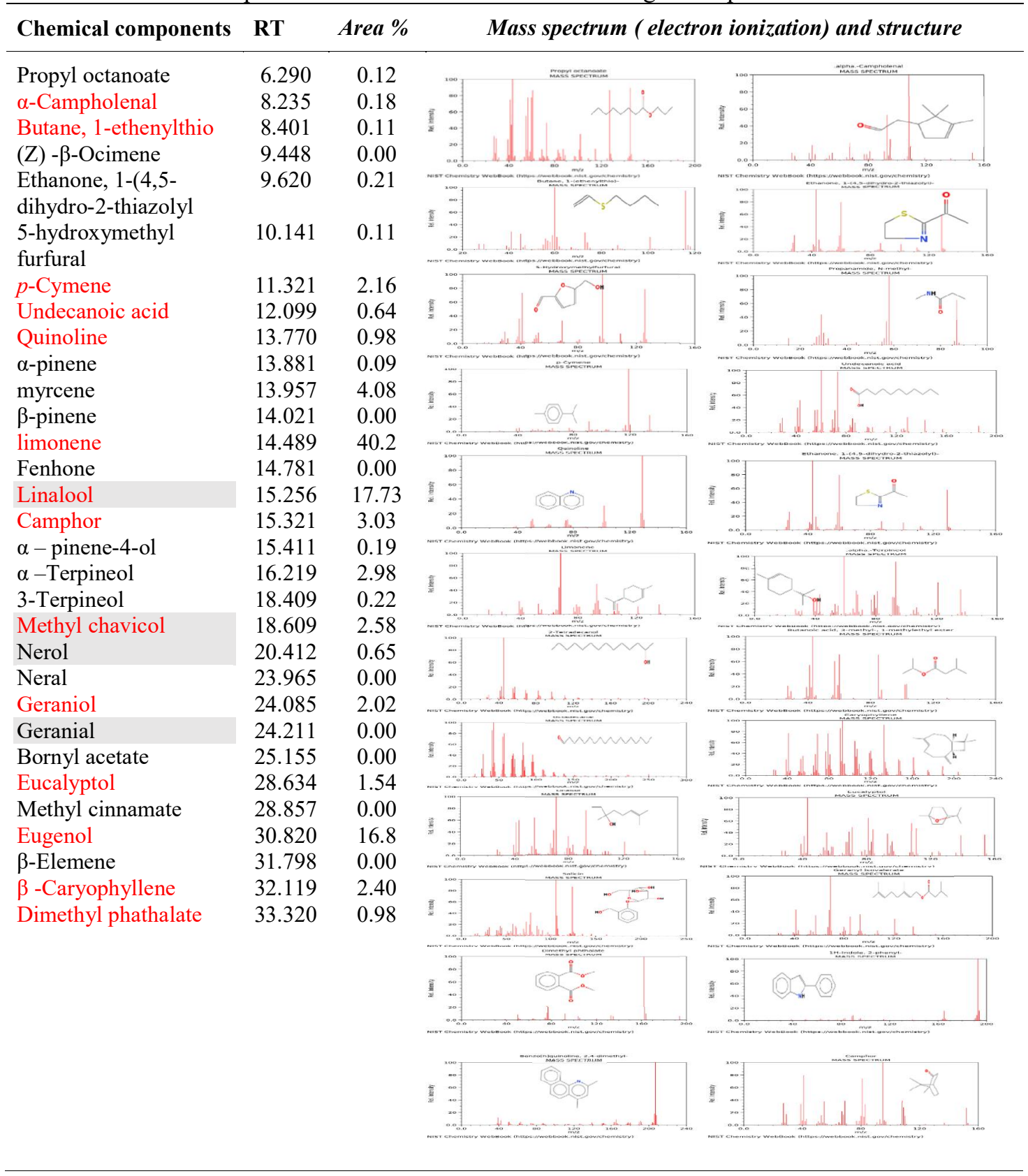




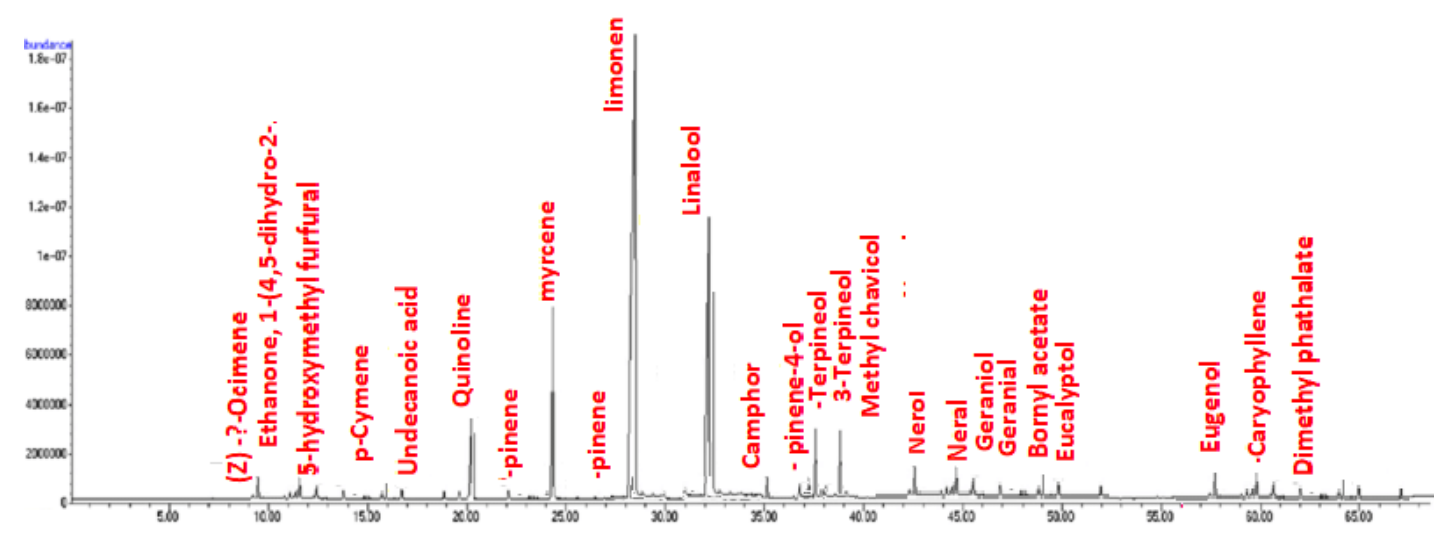

Fig. 5: GC chromatogram of transgenic explants

\section{References}

Allahverdiyev, A. et al., 2001. Investigation of the anticancerogenic effect of the essential oil of Melissa officinalis L. Pharmaceutical \& Pharmacological Letters, 1(1): 26-29.

Altman, A. 2000 Micropropagation of plants, principles and practice. In: Spier, R. E. Encyclopedia of Cell Technology. New York: John Wiley \& Sons. pp. 916-929.

Baiyeri, K.P. and B.N. Mbah, 2006. Surface sterilization and duration of seed storage influenced emergence and seedling quality of African breadfruit (Treculia africana Decne). African Journal of Biotechnology, 5 (15):1393-1396.

Balestrazzi, A., D. Carbonera, and M. Confalonieri, 2000. Agrobacterium tumefaciens-mediated transformation of elite white poplar (Populus alba L.) and regeneration of transgenic plants. J. Genet. Breed., 54: 263-270.

Bansal, M., P. Gaurva, P. Sharmile, P. Pardha-Saradhi, N. Dilbaghi, and A. Chaudhury, 2008. Agrobacterium mediated genetic transformation of tomato for enhanced salt tolerance. The Icfai Journal of Biotechnology, 2 (1): 34-51.

Banu, L.A. and M.A. Bari, 2007. Protocol establishment for multiplication and regeneration of Ocimum sanctum L. Journal of Plant Science, 2: 530-537.

Barbehenn, R.V., C.P. Jones, L. Yip, L. Tran, and C.P. Constabel, 2007. Does the induction of polyphenol oxidase defend trees against caterpillars? Assessing defenses one at a time with transgenic poplar. Oecologia, 154:129-400.

Begun, F. et al., 2000. In vitro clonal propagation of holy basil (Ocimum sanctum L.). Plant Tissue Cult., Rehovot, 10(1):31-37.

Binns, A.N. and M.F. Thomashow, 1988. Cell biology of Agrobacterium infection and transformation of plants. Annu. Rev. Microbiol., 42: 575-606.

Carovic-Stanko, K., S. Orlic, O. Politeo, F. Strikic, I. Kolak, M. Milos, and Z. Satovic, 2010. Composition and antibacterial activities of essential oils of seven Ocimum taxa. Food Chem., 119: 196-201.

Cheng, N.H., 2008. At GRX4, an arabidopsis chloroplastic monothiol glutaredoxin, is able to suppress yeast grx5 mutant phenotypes and respond to oxidative stress. FEBS Lett., 582: 848- 854.

Cheng, N.H., J.Z. Liu, A. Brock, R.S. Nelson, and K.D. Hirschi, 2006. At GRXcp, an Arabidopsis chloroplastic glutaredoxin, is critical for protection against protein oxidative damage. J. Biol. Chem., 281: 26280-26288

Confalonieri, M., B. Belenghi, A. Balestrazzi, S. Negri, G. Facciotto, G. Schenone, and M. Dellodonne, 2000. Genetic transformation and hybridization:Transformation of elite white poplar (Populus alba L.) cv. „Villafranca"e and evaluation of herbicide resistance. Plant Cell Rep., 19: 978-982.

De-Block, M., 1990. Factors influencing the tissue culture and the Agrobacterium tumefaciens mediated transformation of hybrid aspen and poplar clones. Plant Physiol., (93):1110-1116 
Dikbas, N., 2010. Determination of antibiotic susceptibility and fatty acid methyl ester profiles of Bacillus cereus strains isolated from different food sources in Turkey. African Journal of Biotechnology, 9(11):1641-1647.

Gaber, A., M. El-Awady, N.I. Elarabi and M.H. Soliman, 2006. Overexpression of glutaredoxin-2 from cyanobacterium synechocystis pcc 6803 in escherichia coli conferring enhanced salt stress tolerance. Arab J. Biotechnol., 10: 13-22.

Gang, D.R., J. Wang, N. Dudareva, K.H. Nam, J.E. Simon, E. Lewinsohn, and E. Pichersky, 2001. An investigation of the storage and biosynthesis of phenylpropenes in sweet basil. Plant Physiol., 125: 539-555.

Gao, S., C. Ouyang, S. Wang, Y. Xu, L. Tang, and F. Chen, 2008. Effects of salt stress on growth, antioxidant enzyme and phenylalanine ammonia-lyase activities in Jatropha curcas L. seedlings. Plant Soil Environ., 54(9): 374-381.

Gulcin, I., M.E. Buyukokuroglo, M. Oktay, and O. Kufervioglu, 2002. On the in vitro antioxidative properties of melatonin, J. Pineal, Res., 33:167-171.

Hall, R.L. and B.L. Oser, 1965. Recent progress in the consideration of flavoring ingredients under the food additives amendment. III. GRAS Substances. Food Technol., 19:151-197.

Hameed, N., A. Shabbir, A. Ali, and R. Bajwa, 2006. In vitro micropropagation of disease free rose (Rosa indica L.). Mycopath., 4(2):35-38.

Han, K.H., R. Meilan, C. Ma, and S. Strauss, 2000. An Agrobacterium tumefaciens transformation protocols effective on a variety of cottonwood hybrids (genus Populus). Plant Cell Rep., 19: 315320.

Han, X., S. Ma, X. Kong, T. Takano, and S. Liu, 2013. Efficient Agrobacterium-mediated transformation of hybrid poplar Populus davidiana dode $\times$ Populus bollena Lauche. Int. J. Mol. Sci. 14: 2515-2528.

Iijima, Y., R. Davidovich-Rikanati, E. Fridman, D. Gang, E. Bar, E. Lewinsohn, and E. Pichersky, 2004a. The biochemical and molecular basis for the divergent patterns in the biosynthesis of terpenes and phenylpropenes in the peltate glands of three cultivars of basil. Plant Physiol., 136:3724-3736.

Iijima, Y., D. Gang, E. Fridman, E. Lewinsohn, and E. Pichersky, 2004b. Characterization of geraniol synthase from the peltate glands of sweet basil. Plant Physiol., 134:370-379.

Jamal, M.M., I.H. Sharif, M.M. Shakil, A.N.M. Rubaiyath- Bin Rahman, N.A. Banu, M.R. Islam, and M. Nazmuzzaman, 2016. In vitro regeneration of a common medicinal plant, Ocimum sanctum L. for mass propagation. Afr. J. Biotechnol., 15(24): 1269 -1275.

Khanna, H.K. and S.K. Raina, 1998. Genotype x culture media interaction effects on regeneration response of three indica rice cultivars. Plant Cell, Tissue Organ. Cult., Dordrecht, (52): 145- 153.

Koca, H., M. Bor, F. Ozdemir, and İ. Türkan, 2007. The effect of salt stress on lipid peroxidation, antioxidative enzymes and proline content of sesame cultivars. Environ. Exp. Bot., 60: 344-351.

Lewinsohn, E., I. Ziv-Raz, N. Dudai, Y. Tadmor, E. Lastochkin, O. Larkov, D. Chaimovitsh, U. Ravid, E. Putievsky, E. Pichersky, and Y. Shoham, 2000. Biosynthesis of estragole and methyl-eugenol in sweet basil (Ocimum basilicum L.): developmental and chemotypic association of allylphenol O-methyltransferase activities. Plant Science, 160:27-35.

Li, D.-X., X.-J. Du, X.-F. Zhao and J.-X. Wang, 2010. Expression, Purification and activity assay of the recombinant protein of catechol-omethyltransferase from Chinese white shrimp (Fenneropenaeus chinensis). Am. J. Biochem. Biotechnol., 6: 148-154.

Mishra, T., 2015. Protocol establishment for multiplication and regeneration of 'Holy Basil' (Ocimum sanctum L.). An important medicinal plant with high religious value in India. Journal of Medicinal Plants Studies, 3(4): 16-19.

Moghaieb, R.E.A., S. Hirofumi, and F. Kounosuke, 2004. shoot regeneration from gus-trans formed tomato (Lycopersicon esculentum) hairy root. Cellular \& Molecular Biology Letters, 9:439-449.

Moradkhani, H., E. Sargsyan, H. Bibak, B. Naseri, M. Sadat-Hosseini, A. Fayazi-Barjin, and H. Meftahizade, 2010. Melissa officinalis L., a valuable medicine plant: A review. Journal of Medicinal Plants Research, 4(25): 2753-2759.

Morsy, A.M., 2007. Molecular variation of Achillea fragrantissima (Forssk) SCH. BIP growing in five areas of south sinai. Int. J. Agri. Biol., 9(1): 11-17. 
Mosandl, A., K. Fischer, U. Hener, P. Kreis, K. Rettinger, V. Schubert, and H. G. Schmerr, 1991. Stereoisomeric flavor compounds. 48. Chirospecific analysis of natural flavors and essential oil using multidimensional gas chromatography. J Agric Food Chem 39:1131-1134.

Movahedi, A., J. Zhang, R. Amirian and Q. Zhuge, 2014. An efficient Agrobacterium-mediated transformation system for poplar. Int. J. Mol. Sci., 15: 10780-10793.

Murashig, T. and F. Skoog, 1962. A revised medium for rapid growth and bioassays with tobacco tissue cultures. Physiol. Plant, 15: 473-497.

Nadel, B.L., G. Hazen, R. David, A. Huttermann, and A. Altman, 1992. In vitro propagation of Populus species: response to growth regulators and media composition. Acta. Hortic., 314:61-68.

Newman, H.N., 1996. Focal Infection. Journal of Dental Research 75: 1912 \pm 9.

Noguera, V., O. Walker, N. Rouhier, J.P. Jacquot, I. Krimm, and J.M. Lancelin, 2005. NMR reveals a novel glutaredoxin-glutaredoxin interaction interface. J. Mol. Biol., 353: 629-641.

Pasqual, M., L. Pio, A.C.O. Oliveira, and J.D.R. Soares, 2012. Flow Cytometry Applied. In: Leva, A and Rinaldi, L. M. R. (Ed.). Recent Advances in Plant in vitro Culture: InTech, 14.

Patel, R.P., R. Singh, and R.R. Rao, 2016. Differential response of genotype $\times$ environment on phenology, essential oil yield and quality of natural aroma chemicals of five Ocimum species. Industrial Crops and Products, 87:210-217

Pattnaik, S. and P.K. Chand, 1996. In vitro propagation of the medicinal herbs Ocimum americanum L. syn. O. canum Sims. (hoary basil) and Ocimum sanctum L. (holy basil). Plant Cell Repo, Berlin, 15: $846-850$

Phippen, W.B. and J.E. Simon, 2000. Shoot regeneration of young leaf explants from basil (Ocimum basilicum L.), In vitro Cell. Dev. Biol. Plant Largo, 36:250-254.

Prakash, P. and N. Gupta, 2005. Therapeutic Uses of Ocimum sanctum Linn (Tulsi) with a Note on Eugenol and Its Pharmacological Actions: A Review. Indian Journal of Physiology and Pharmacology, 49:125-131.

Ros-Barceló, A., R. Muñoz, and F. Sabater, 1987. Lupin peroxidases. I. Isolation and characterization of cell wall-bound isoperoxidase activity. Physiol. Plant. 71: 448-454.

Rouhier, N., E. Gelhaye and J.P. Jacquot, 2004. Plant glutaredoxins: Still mysterious reducing systems. Cell Mol. Life Sci., 61: 1266-1277.

Rouhier, N., S.D. Lemaire, and J.P. Jacquot, 2008. The role of glutathione in photosynthetic organisms: emerging functions for glutaredoxins and glutathionylation. Annu. Rev. Plant Biol., 59:143-166.

Rutledge, C.B. and G.C. Douglas, 1988. Culture of meristem tips and micropropagation of 12 commercial clones of poplar in vitro. Physiol. Plant, 72: 363-373.

Saha, S., P.D. Ghosh, and C. Sengupta, 2010. An efficient method for micropropagation of Ocimum basilicum L. Indian J. Plant Physiol., 15 (2): 168-172.

Sharzad, A., and S.A. Siddiqui, 2000. In vitro organogenesis in Ocimum sanctum L. - A multipurpose heb. Phytomorphology, Delhi, 50: (1), 27-35.

Singh, N.K. and C.B. Sehgal, 1999. Micropropagation of "Holy basil" (Ocimum sanctum L.) from young inflorescens of mature plants. Plant Growth Regul., Dordrecht, 29:161-166.

Sishu, R., S.Tadesse, F. Bucar, and K. Asres, 2010. Composition and the antioxidant activity of the essential oils of Ocimum basilicum var. thyrsiflorum and Ocimum americanum. Int J Essent Oil Ther., 4:64-8.

Stanturf, J.A., C. van-Oosten, D.A. Netzer, M.D. Coleman, and C.J. Portwood, 2001. "Ecology and silviculture of poplar plantations, "in Popular Culture in North America, eds D. I. Dickmann, J. G. Isebrands, J. E. Eckenwalder, and J. Richardson (Ottawa, ON: NRC Research

Statistical Graphics Corporation, COSTAT (1999) STATGRAPHICS statistical graphics system, STSC., Inc., Englewood Cliffs, NJ.

Steel, R.G.D. and J.H. Torrie, 1980. Principles and Procedures of Statistics. $2^{\text {nd }}$ ed. New York: McGrawHill.

Tausz, M., H. Sircelj, and D. Grill, 2004. The glutathione system as a stress marker in plant ecophysiology: is a stress-response concept valid. J. Exp. Bot., 55: 1955-1962.

Tsasi, G., T. Mailis, A. Daskalaki, E. Sakadani, P. Razis, and Y. Samaras, 2017. The effect of harvesting on the composition of essential oils from five varieties of Ocimum basilicum L. Cultivated in the Island of Kefalonia, Greece. Plants, 6:41. 
Tzfira, T., C.S. Jensen, W. Wang, A. Zuker, B. Vinocur, A. Altman, and A. Vainstein, 1997. Transgenic Populus tremula: a step-by-step protocol for its Agrobacterium-mediated transformation. Plant Molecul. Biol. Reporter, 15: 219-235.

Vieira, R.F. and J.E. Simon, 2006. Chemical characterization of basil (Ocimum spp.) based on volatile oils. Flavour Fragr. J., 21:214-221.

Wang, Q., F. Yuan, Q. Pan, M. Li, G. Wang, J. Zhao, and K. Tang, 2010. Isolation and functional analysis of the Catharanthus roseus deacetylvindoline-4-Oacetyltransferase gene promoter. Plant Cell Rep., 29(2):185-192.

Werker, E., E. Putievsky, U. Ravid, N. Dudai and I. Katzir, , (1993). Glandular Hairs and Essential Oil in Developing Leaves of Ocimum basilicum. Ann. Bot. 71, 43-50.

Wesolowska, A. and D. Jadczak, 2016. Composition of the essential oils from inflorescences, leaves and stems of Ocimum basilicum 'Cinnamon' cultivated in North-western Poland. Journal of Essential Oil Bearing Plants, 19(4):1037-1042.

Xiong, L.Z., P.K.A. Ling, and S. Hussein, 2009. Callus induction of Ocimum sanctum and estimation of its total flavonoids content. Asian Journal of Agricultural Sciences, 1: 55-61. 